\title{
食物アレルギー診療ガイドライン2005解説
}

\section{第10章 食物アレルギーに対する社会的対応}

\author{
柴 田 瑠美子 \\ 国立病院機構福岡病院小児科
}

はじめに

今日の食物アレルギーの増加には, アレルゲン食品 の多様化, 加工食品等を通じてのアレルゲン食品の不 用意な摂取があり，このような食品に溢れた社会生活 において食物によるアレルギー誘発を避ける適切な対 応が求められている.

加工食品によるアナフィラキシーを予防するためにア レルゲン食品表示義務の法的規制が始まり，アレルギー 児にはかなりの恩恵となっているが, 店頭販売での事故 は多く, 食品業界を含めた食物アレルギーの社会的認識 は充分ではない. 保育園・幼稚園・学校での集団生活に おける食物アレルギー児への対応では，保育，教育ス夕 ッフの食物アナフィラキシーの知識・理解の向上と給食 対応をどのように行うかが最も切実な問題である. ガイ ドラインの社会的対応では, 園, 学校における食物アレ ルギー誘発の現状を踏まえ, 医療機関が患者・家族のた めに園・学校に診断書を通して情報を提供し対応を指導 することの重要性を述べている1).

\section{1. 園や学校における食物アレルギー誘発の現状と対応}

学校や園での食物アレルギーの現状については, 2001年代に欧米での調査報告が合いついでなされてお り，米国アナフィラキシーネットワーク（USピーナ ッツ・ナッツアレルギー登録) での調査では, 園およ び学校での誘発が16\% (750例) でみられており，そ の64\%はデイケア，プレスクールであり，36\%は小学 校, 中学校である ${ }^{2)}$. NY地区における園や学校での 誘発は 2 年間76例で, アレルゲン食品は, ミルク, ピ ーナッツ，卵，ナッツの順であり，32\%で喘鳴，10\% で嘔吐，1例ショックを呈しエピペンは 6 例で施行さ れている3).

フランスでは, 個々の重症食物アレルギー児に個別
ケアプロジェクトPCPが受けられる体制があり，学童 38例の確定診断例（75\%はピーナッツ）の33\%に40回 のアナフィラキシーがあり，22\%が学校で起こってい る. $27 \%$ は給食でのアレルゲン食品の誤摂取であり, $10 \%$ は加工食品への混入によると考えられている．工 ピペンの学校での保管状況はさまざまであり, 誘発時 の学校スタッフの知識の確認, 訓練が必要であるとし ている ${ }^{4)}$.

スウェーデンでは，学校での除去食をうけている児 童は85\%はヘルスケア専門官のコンサルト，68\%が医 師の確定診断を受けており，27／196例で呼吸困難, 9 例でアナフィラキシーがみられている ${ }^{5)}$.このよう な状況から, 欧米では学校における食物アレルギーの 対応ガイドラインや，アレルギー専門医，小児科医， 家族, 学校スタッフの連携を行うことの重要性が報告 されている ${ }^{6,7)}$. 学校ナースだけでなく他の職員のア ナフィラキシーの早期確認, 緊急時のエピペンなどの トレーニングの必要性, 個々の学童の情報やガイダン スをかかりつけ医から得ることを针めており，このよ うなトレーニングが常に再検討, 実施されることが必 要であると述べている.

我が国の文部科学省の平成16年度調査では小・中 . 高の 1200 万人中の食物アレルギー児は $2.6 \%$ (33万人), アナフィラキシー $0.14 \%$ （17800人）の有症率が報告 されている。食物アレルギー患者会のアナフィラキシ 一発症402例の発症場所の調査により，36例 $4.5 \%$ に学 校での誘発がみられている ${ }^{8)}$. 学校給食では, 実施率 は小学校で $99 \%$, 中学で $82 \%$ と高いが, 今井らの調査 では，10190の学校調理場中，54\%で食物アレルギー 学童への対応が行われており, その 6 割が除去食（ア レルゲン食品を除く）のみ，4割が対応食を行ってい ることが明らかになっている ${ }^{9 !}$. 食物アレルギー児が いる学校の割合は76\%におよぶことが報告されてお り, 給食時に637例の誘発事故 $(2.3$ 万に 1 人) があり, 
全国で 1 日1.3件の発症があるとされている.

誘発原因のほとんどは給食時であり園や学校での給 食時の対応の取り組みが必要である。学童期の食物ア レルギーは, 幼児期までにアレルゲン食品の解除がで きなかった症例や新たに発症した症例でありアナフィ ラキシー既往者が少なくない. 従って, 集団生活, 給 食開始前に患児の具体的な食物アレルギー症状と対応 法, 必要な除去食品について医療側からの情報を提供 し, 園・学校での対応手順を決めておくことが重要で ある10).

\section{2. 園における給食対応}

保育園ではすべて給食を提供しており, 栄養士がい る場合が多いためアレルギー児に対する理解や園で対 応しようとする姿勢は強い. 幼児期は, 食物アレルギ ーとアトピー性皮膚炎を合併することが多いため，ア レルゲン食品の除去がアナフィラキシー回避だけでな く, 皮䖉炎への影響を心配して過剩な除去を希望する 家族が多いことも事実である。保育園, 幼稚園では, 食事は 1 日の生活の重要な時間であり, 食育に対する 考えは園では重要視されており, 除去の必要性に対す る指示書は園側からの要望が高い.

\section{3. 除去食指示書, 診断書の内容と書き方}

除去食指示書（医師意見書）は，アナフィラキシー 回避, 不適切な除去食回避のため診断書である. 個々 の対象児のアレルゲン食品と誘発症状 (可能性を含 め), 対応を指示書・診断書で園・学校に連絡し, 食 物アレルギー児の受け入れと安全な給食の提供ができ るように情報提供をおこなうものである，具体的なア レルゲン食品を知らせることで, 提供できる給食対応 を提示してもらい, 多種食物アレルギーなどで対応が 困難な場合は家族の弁当が適当な場合もあることを助 言する．主な内容は，1）除去を要する食品名，2） 摂取により出現する可能性のある症状, 3 ) 緊急対応 法，4）再評価期間である. 表 1 に園児のアレルギー 除去食に関する診断書 (指示書), 表 2 に学校におけ るアナフィラキシーショックの診断書例を示す.

1 ) 除去を要する食品名：個々の症例で原因アレルゲ ン食品は異なっており, 現在除去を要する食品名を記 入する。

多種食物にアナフィラキシーがある場合は, 現在の 給食メニューでの対応, 別メニュー調理が困難である
ため, 家族の作る弁当を選択することも必要である. 多くの家族はコピー弁当で内容に差がないように工夫 してつくられているようである.中には同じ食器に移 し変えて給食で提供する学校もある。入学や学年変更 で教師, 栄養士, 学校スタッフと給食内容をチェック して常に連絡しあい, 事故がないように対策を行って おく.

同時にアレルゲン食品を材料とする日常食品, 料理 名の具体的な除去食品リストを提示しておくと給食対 応を行う園では食品の選択に役立つ.アナフィラキシ 一児では関連食品すべての完全除去が必要であるが, 幼児期〜学童で卵, 牛乳などの高温加熱食品（焼菓子 など), 小麦, 大豆での発酵食品など摂取できている ものは利用可能であることが多く, 食品リス卜表で具 体的に示すことも受け入れ側のアレルゲン食品の認識 には重要である。これらの食品リスト表は園が用意し たものなどでもよい.

2) 摂取により出現する可能性のある症状：除去食中 にアレルゲン食品の䛊食事故でアナフィラキシーを呈 することは多く、アレルギー児の誘発症状既往または 誘発の可能性があることを示し, 園・学校に招ける 個々の患児のアレルギー重症度の理解を得る。ショッ ク, 咳こみ, 呼吸困難, 嘔吐, 顔面発赤, 蕁麻疹など 具体的な症状の番号を記入する.

またアナフィラキシー児では, 食事以外にアレルゲ ン食品の接触によって症状が誘発されることがあるこ とを記載しておく。とくに周りで飲用している牛乳に は注意が必要である。調理実習での卵, 小麦, 牛乳を 使う場合, 行事での豆まきのナッツ, 大豆, ソバ打ち 体験, 小麦粘土などアレルゲン食品との接触を避ける.

3) 緊急対応法：誤食などによる急な誘発症状に対し て, 必要な内服薬, 医療機関受診のタイミングを記入 する. 園・学校での可能な限りの協力を得ることが重 要である. 内服薬の保管ができない場合は, 毎日, 患 児のカバン, バックなどに携帯させ, 発症時の家族へ の連絡時に内服介助依頼を行う.

内服薬は，抗ヒスタミン薬，ステロイドが処方され る．年長児ではプレドニンの錠剤が利用できるが，低 年齢児の重症例では抗ヒスタミン薬とステロイド合剤 であるセレスタミン®が分量も少なく末またはシロッ プで服用しやすい.

ショック既往者には，アドレナリン自己注射器エピ 
表 1 園児のアレルギー除去食に関する診断書（主治医意見書）

巟童氏名 さん（男・女）平成 年 日生

診断名：

本児は診察・検査の結果、以下の食物については食事からの除去が必要と考えられます。

1. 除去が必要な食品名は以下の通りです。

・食物名

・牛乳アレルギーの場合の使用できるミルク名

※除去食品の詳細は別紙に示します。

2. 摂取した場合に出現する可能性のある症状は以下の通りです。

食品名

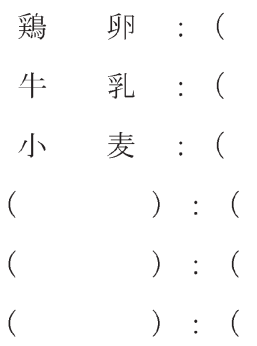
症状

$$
\begin{gathered}
\text { 未捸取のため不明 ） } \\
\text { 未摂取のため不明 ） } \\
\text { 未攝取のため不明 ） } \\
\text { 未摄取のため不明 ） } \\
\text { 未摄取のため不明 ） } \\
\text { 未摄取のため不明 ） }
\end{gathered}
$$

即時型反応 : (1)ショック, (2)咳き込み, (3)呼吸困難, (4)嘔吐・腹痛, (5)顔面紅潮, (6)尋麻疹, (7)瘙痒感 非即時型反応：(8)湿疹, 9)掻痒感, (10)下痢

3. 摂取後に症状が出現した場合の対処法および緊急の対応は以下の通りです。

(1)内服薬 :

(2) その他 :

本診断書 (意見書) の内容については、（ $3 ， 6 ， 12$ ) カ月後に再評価が必要です。

平成 年 月

医院名

電話番号

医師名

印 
表 2 食物アレルギーによるアナフィラキシーショックに関する診断書

（主治医意見書）

(学校用 参考例)

児童（生徒）氏名

さん（男・女）平成

年

日生

診断名：

本児（生徒）は診察・検查の結果、以下の食物についてはアレルギーを有し、アナフィラキシーショ ックを起こす可能性がありますので食事からの除去が必要です。

1. 除去が必要な食品名は以下の通りです。

- 食物名（

2. 摄取した場合に出現する可能性のある症状は以下の通りです。（該当する症状にメをしてください） 食品名 症状

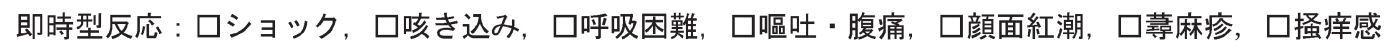
非即時型反応：口湿疹， 口掻痒感， 口下痢

3. 摂取後に症状が出現した場合の対処法および緊急の対応は以下の通りです。

(1)内服薬 :

(2)外用薬 :

(3)乞の他 :

緊急医療機関

電話

本診断書（意見書）の内容については、（ $3 、 6 、 12 ）$ カ月後に再評価が必要です。

平成年早

医院名

電話番号

医師名 
ペン®が処方されていることがありそのことを記載し ておく、呼吸困難, ショックではエピペン®が使用で きるように援助または緊急受診を指導する。このエピ ペン®の保管, 使用については学校での取り扱いに規 定がなく現在のところ日本では患児自身か家族に限ら れているが対応手順を討議しておく.エピペン携帯や 園・学校の保管を含め, アナフィラキシー発症時の注 射施行が可能な環境つくりが望まれている.

学校には“学校における食物アナフィラキシー対応 マニュアル”が配布されて抢り, 同冊子のアナフィラ キシーショックに関する診断書の形式で学校から依頼 されることもある。内容的には同様であり上記解説を 参考に情報を記入する。

学校側には, アナフィラキシー誘発時の具体的な緊 急時の連絡先リストを作成し, 家族への連絡先, 想定 される緊急時の対応法, 内服する薬の名前, 医療機関 の受診手順についてマニュアルを参考に作成するよう 指導する.

4 ) 再評価期間 : 小児の食物アレルギーでは年齢とと もに自然耐性化することも多く，負荷試験などによる 除去食の解除にともない指示書の再発行を行う。園で は 6 カ月または 12 力毎，学校では 1 年毎の再発行を 行うことが多い. 除去食品が変わらなくても現在の必 要な情報を提供することで認識を新たにしてもらうた めにも再評価は重要である.

5 ）その他：施設・学校職員全員でこれらの情報を把 握し，他の園児，学童を含めた食物アレルギー児への 理解をはかることが大切である。学童間では食事が異 なることから, 差別や特別視につながりやすい。 また 無理にアレルゲン食品を強要することがない様に食物 アナフィラキシーについての知識を授業などでみんな に話しておくように依頼する。

食物アナフィラキシー児の中にはシックハウス, 化 学物質過敏症を有する例もあり, 園でのワックスや消 毒などは，園の休みに損願いするなど環境対策への協 力が必要なことがある.

\section{おわりに}

家庭における食生活と同様に, 園や学校での食事は 安全に楽しく提供されるべきである。学校でも食育を 重視した考えが提唱されており, 給食はその実践の場
であり，食物アレルギー児を受け入れることで家族， 医療機関と連携して知識を高対応の充実をはかる心゙ きである。学校のアレルギー児を受ける熱意の差に大 きく左右されるのが現状であるが，患児・家族の要望 と医療側の適切な指導・指示で対応がスムーズに行く ことも多く，このような実績を増やしていくことが必 要であると思われる.

欧米では学校ナース, 職員のエピペン使用のトレー ニングが行われており，除去食対応によるアナフィラ キシー回避のみでなく, 誘発を予測した準備が必要で ある。アレルギー児を診療する医療側は, 食物アレル ギー, アナフィラキシーの理解の向上に向けて, 情報 提供, 医療協力を通して働きかけを行ってゆくことが 何より大切である。

\section{文献}

1. 向山德子 西間三馨監修: 食物アレルギー診療ガ イドライン2005東京 協和企画 2005:72-75.

2. Sicherer SH, Furlong TJ, DeSimone J, Sampson HA. The US Peanut and Tree Nut Allergy Registry: characteristics of reactions in schools and day care. J Pediatr 2001. 138: 560-5.

3. Nowak-Wegrzyn A, Conover-Walker MK, Wood RA. Food-allergic reactions in school and preschool. Arch Pedatr Adolesc Med 2001; 155: 790-5.

4. Moneret-Vautrin DA, Kanny G, Morisset M, Flabbee J, et al. Food anaphylaxis in schools: evaluation of the management plan and the efficiency of the emergency kit. Allergy 2001; 56: 1071-6.

5. Gunnarsson N, Marklund B, Ahlstedt S, et al. Allergy-like conditions and health-care contacts among children with exclusion diets at school. Scand J Caring Sci. 2005; 19: 46-52.

6. Sheetz AH, Goldman PG, Millett K, et al. Guidelines for managing life-threatening food allergies in Massachusetts schools. J Sch Health. 2004; 74: 155-60.

7. Munoz-Furlong A. Food allergy in schools: concerns for allergists, pediatricians, parents, and school staff. Ann Allergy Asthma Immunol. 2004; 93 (5 Suppl 3): S47-50. 
8. 神奈川芳行, 海老澤元宏, 今村知明. 食物アレル ギー患者がアナフィラキシーを誘発した際の食品 形態, 販売形態, 対処方法及び食品原材料名等の 調査結果について 日本小児アレルギー学会誌 $2005 ; 19: 78-86$.

9. 今井孝成, 海老澤元宏. 学校給食における食物ア
レルギーの現状と対策. 日本小児アレルギー会誌. $2004 ; 18$ :251-255.

10. 柴田瑠美子 ガイドラインに基づく保育園・幼稚 園・学校における食物アレルギー対応 日本小览 アレルギー学会誌 $2007 ； 21 ： 56-60$. 